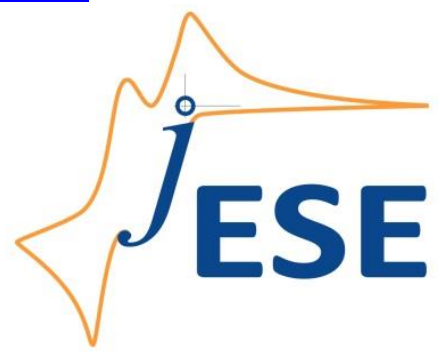

Open Access : : ISSN 1847-9286

www.jESE-online.org

Original scientific paper

\title{
Internal resistance and temperature change during over- discharge of lead-acid battery
}

\author{
Balázs Broda ${ }^{凶}$, György Inzelt \\ Institute of Chemistry, Laboratory of Electrochemistry and Electroanalytical Chemistry, \\ Eötvös Loránd University, Pázmány P. s. 1/A, H-1117 Budapest, Hungary
}

Corresponding authorsE-mail: ${ }^{凶}$ balazsbroda@gmail.com

Received: October 26, 2017; Revised: January 29, 2018; Accepted: January 29, 2018

\begin{abstract}
In recent decades, more and more electronic systems (start-stop, drive-by-wire, brakeby-wire) have been developed in the automotive industry therefore reliable power sources are necessary. It is essential to understand thoroughly the detailed behaviour of the battery to increase its efficiency, stability and monitorability which is the most popular field nowadays. Over-discharge plays an important role in aging because it increases the probability of initiation of grid corrosion, sulfation and loss of active mass. In this work, the effects of over-discharge of lead-acid battery have been investigated via internal resistance increase and temperature change separately for both the negative and the positive electrode. Most of the measurements were carried out in a prepared test cell (which contained a negative and a positive plate, an $\mathrm{Ag} \mid \mathrm{Ag}_{2} \mathrm{SO}_{4}$ reference electrode, a shunt for measuring current accurately) connected to a dummy battery and an electronic load.
\end{abstract}

Keywords

Energy storage; Deep discharge; Aging; Battery sensor

\section{Introduction}

Despite of the fact that the lead-acid battery is a 150 -year-old system, its over-discharge characteristic is a less investigated area. During this process, different reactions can occur which lead to the aging of the battery (for example sulfation, loss of active mass or loss of water) [1-4]. In the $21^{\text {st }}$ century, lead-acid batteries are still used in most of cars for starting the gasoline or diesel engine and for the operation of the electronic system (drive-by-wire, brake-by wire, start-stop systems) too. In this case, reliable and well-monitorable power sources are necessary. For this purpose, better understanding of over-discharge is still necessary.

At the end of the $20^{\text {th }}$ century, Garche et al. [5] estimated the basic reactions during overdischarge. The cell voltage, the potential of the positive and the negative electrode, the intensity 
of gas evolution and the density of sulfuric acid at the top of the cell were measured. It was stated that the basic reaction during discharge proceeded to a lesser extent and was replaced by other reactions (for example increased gas evolution). In case of positive electrode, the capacity loss is mainly caused by mechanical stress, because of different molar volumes of the reactants ( $\left.V_{\text {lead-dioxide }}: V_{\text {lead-sulfate }}: V_{\text {lead }}=1.4: 2.7: 1.0\right)$. In case of negative electrode, the main reason of the aging is the irreversible oxidation of the expanders.

This capacity loss was investigated by Blank et al. [6] setting depth of discharge (DOD) from $100 \%$ to $130 \%$. It was stated that significant part of the initial capacity was lost because of overdischarge just after a few cycles. The amount of decreasing was closely related to DOD level, at higher DOD, the loss of capacity was also larger. It is also stated by the authors that the area of deep discharge has so far been mostly neglected in published research apart from fundamental material investigations [7].

In this paper, we present the effects of over-discharge on the internal resistance of the negative and the positive electrode and the whole cell and on the temperature of the electrolyte at different places of the cell (in the vicinity of the negative and the positive electrode and in the bulk solution).

\section{Experimental}

Two types of batteries were investigated. We used a Furukawa HiDash battery (type: flooded, voltage: $12 \mathrm{~V}$, capacity: $48 \mathrm{Ah}$ ) for the internal resistance measurements and a test cell which contains a negative and a positive plate of a dry Unibat battery (type: flooded, voltage: $12 \mathrm{~V}$, capacity: 9 Ah) and $650 \mathrm{ml} 37 \mathrm{~m} / \mathrm{m} \%$ sulfuric acid for temperature experiment.

\section{Internal resistance measurement}

The potential of the positive and the negative electrode against $\mathrm{Ag} \mid \mathrm{Ag}_{2} \mathrm{SO}_{4}$ reference electrode and another cell voltage were measured by using labjack data acquisition device. We apply $4.8 \mathrm{~A}$ current [which is the $C / 10$ current for a battery which capacity $(C)$ is $48 \mathrm{Ah}$ ] until it reduced to the $10 \%$ of its initial value. During this procedure, we measured the impedance of the battery every 10 minutes at $1 \mathrm{kHz}$ excitation frequency which is good approximation to the battery's internal resistance (Figure 1 ). The $1 \mathrm{kHz}$-resistance $R_{1 \mathrm{kHz}}$ is defined as the real part of the battery impedance at $1 \mathrm{kHz}$ frequency. This is a practical definition, since it is quickly measurable with an active excitation device. The standard handheld battery testers usually measure this value. [8]

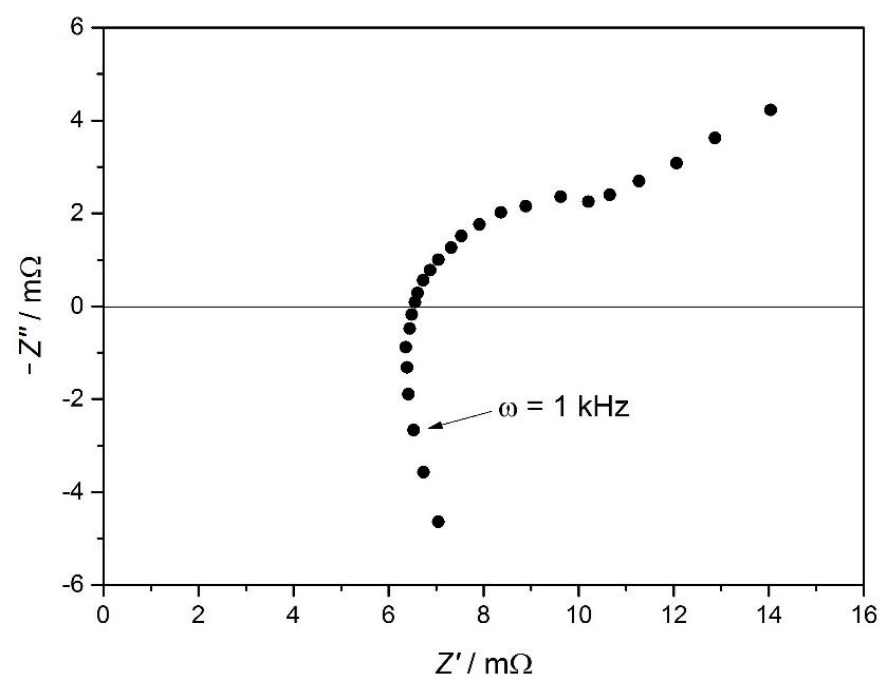

Figure 1. Measured impedance spectrum of the examined cell during discharge (Nyquist plot) 


\section{Temperature experiment}

$\mathrm{An} \mathrm{Ag}\left|\mathrm{Ag}_{2} \mathrm{SO}_{4}\right|$ saturated aqueous $\mathrm{K}_{2} \mathrm{SO}_{4}$ solution (0.69 $\mathrm{V}$ vs. SHE) reference electrode and J-type thermocouples were used. The schematic representation of the experimental system is shown in Figure 2.

Four thermocouples were used to measure the temperature at different places in the cell, their positions are presented in Figure 3. We used a heat chamber to hold the external temperature constant $\left(25^{\circ} \mathrm{C}\right)$.

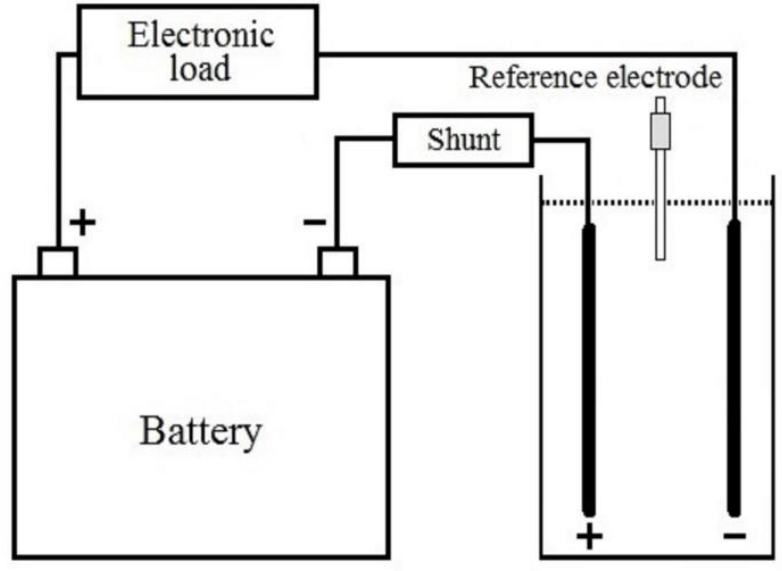

Figure 2. Experimental system

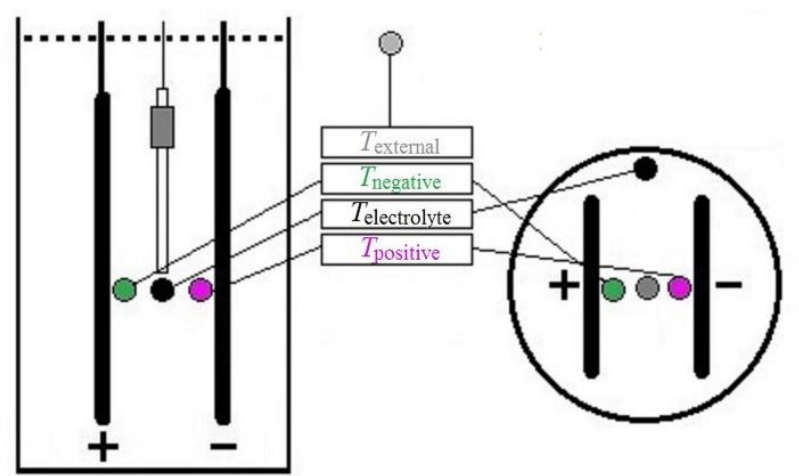

Figure 3. Temperature measurement

The procedure is summarized in Table 1.

Table 1. Procedure of the measurements

\begin{tabular}{|c|c|c|c|}
\hline \multicolumn{3}{|c|}{ Operation (details) } & \multirow{2}{*}{$\begin{array}{c}\text { Circumstances }\left(T=25^{\circ} \mathrm{C}\right) \\
-\end{array}$} \\
\hline 1 & \multirow{2}{*}{ Preparation } & Cell preparation & \\
\hline 2 & & Immersion & $U_{\text {cell }}>2.1 \mathrm{~V}$ \\
\hline 3 & \multirow{6}{*}{ Pretreatment } & Charge & $I_{\lim }=0.16 \mathrm{~A} ; U_{\text {lim }}=2.4 \mathrm{~V} ; t=2 \mathrm{~h}$ \\
\hline 4 & & Discharge & $I=0.16 \mathrm{~A} ; t=1 \mathrm{~h}$ \\
\hline 5 & & Charge & $I_{\lim }=0.16 \mathrm{~A} ; U_{\lim }=2.4 \mathrm{~V} ; t=2 \mathrm{~h}$ \\
\hline 6 & & Discharge & $I=0.16 \mathrm{~A} ; t=1 \mathrm{~h}$ \\
\hline 7 & & Charge & $I_{\lim }=0.16 \mathrm{~A} ; U_{\lim }=2.4 \mathrm{~V} ; t=2 \mathrm{~h}$ \\
\hline 8 & & Discharge & $I=0.16 \mathrm{~A} ; t=1 \mathrm{~h}$ \\
\hline 9 & \multirow{2}{*}{ Achieving full charge } & Charge & $I_{\lim }=0.16 \mathrm{~A} ; U_{\lim }=2.4 \mathrm{~V} ; I<0.016 \mathrm{~A}$ \\
\hline 10 & & Delay & - \\
\hline 11 & Capacity measurement & Discharge & $I=0.16 \mathrm{~A} ; U_{\text {cell }}<1.75 \mathrm{~V}$ \\
\hline 12 & \multirow{2}{*}{$\begin{array}{c}\text { "Over-discharge" } \\
\text { Setting DOD (100·x\%) }\end{array}$} & Discharge & $I=0.16 \mathrm{~A} ; t=t_{\text {capacity measurement }} \cdot(x-1)$ \\
\hline 13 & & Delay & $t=1 \mathrm{~h}$ \\
\hline 14 & \multirow{2}{*}{ „Recharge” } & Charge & $I_{\lim }=0.16 \mathrm{~A} ; U_{\lim }=2.4 \mathrm{~V} ; t=16 \mathrm{~h}$ \\
\hline 15 & & Delay & - \\
\hline
\end{tabular}


In step $12, x$ can be $1.0,1.1$ and 1.2 , which means that the DOD level is $100 \%, 110 \%$ and $120 \%$. The duration of step 12 is the product of the duration of step 11 ( $t_{\text {capacity measurement }}$ ) and $x-1$.

\section{Results and discussion}

\section{Internal resistance measurement}

Negative electrode

In Figure 4 (regarding to the end of step 11, step 12 and 13 and the beginning of step 14 of Table 1), it can be seen that during the over-discharge (between ca. 3-8 $\mathrm{h}$ ) the negative electrode's internal resistance changed to nearly 100 times of its initial $2-3 \mathrm{~m} \Omega$ value when a large change in the potential of the negative electrode occurred. When the potential has become practically constant (there is only a small decrease because of the uncertainty of potential measurement), the electrode's internal resistance has begun to decrease at a similar rate to the previous one and reached about 2 times of its initial value. The internal resistance of the negative electrode hasn't changed until the end of discharge, but when the current has become zero (between ca. 8-9 h) a significant increase could be observed. This process lasted until the charging has been started. During recharging (between ca. 9-16 h), the internal resistance highly decreased and returned to its initial value after several minutes.

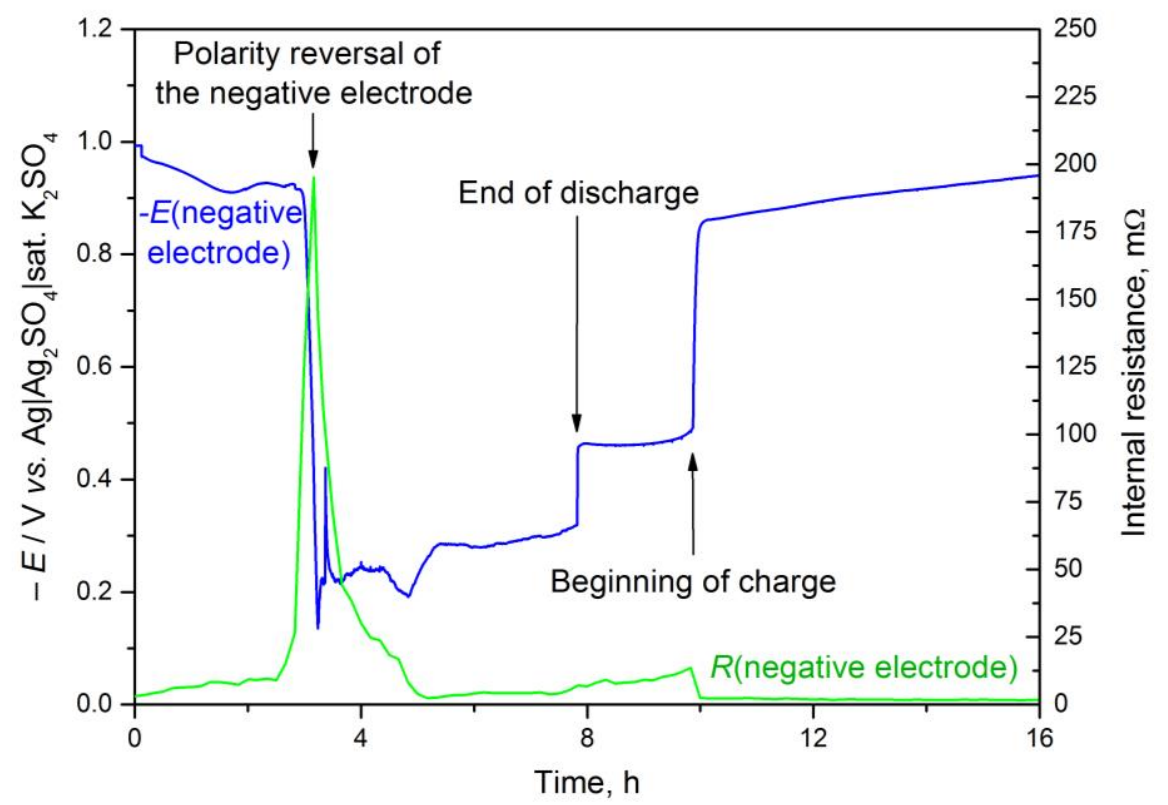

Figure 4. Change of the potential of the negative electrode (multiplied by minus 1) and internal resistance during a discharge-charge cycle

During discharge (between ca. 0-3 h), porous metallic lead is converted to lead sulfate at the negative electrode (Reaction 1 ).

$\mathrm{Pb}+\mathrm{HSO}_{4}^{-} \rightarrow \mathrm{PbSO}_{4}+\mathrm{H}^{+}+2 \mathrm{e}^{-}$

(Reaction 1)

The specific volume of $\mathrm{PbSO}_{4}$ is approximately 3 times higher than the specific volume of $\mathrm{Pb}$ and its conductivity is lower by orders of magnitude [9]. Thus, the porosity decreases during this process as well as the pores become clogged (so the diffusion coefficient of the different species in the electrolyte decreases). At the same time, sulfuric acid reacts with lead, that's why its concentration becomes smaller and the amount of acid required for the reaction isn't available on the surface of the active material. As the result of these two processes, the potential of the negative electrode and the internal resistance highly increase. 
The Nernst equation provides an approximate calculation of the potential of the negative electrode. Although the system is not in equilibrium during discharge, this relationship can be used to interpret the direction of the processes.

$$
E_{\mathrm{PbSO}_{4} / \mathrm{Pb}}=E_{\mathrm{PbSO}_{4} / \mathrm{Pb}}^{o}+\frac{R T}{2 F} \ln \frac{a_{\mathrm{PbSO}_{4}} a_{\mathrm{H}^{+}}}{a_{\mathrm{Pb}} a_{\mathrm{HSO}_{4}^{-}}}
$$

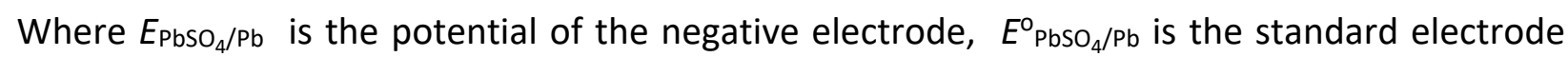
potential of the $\mathrm{PbSO}_{4} / \mathrm{Pb}$ system $(-0.356 \mathrm{~V}$ vs. SHE), $R$ is the gas constant, $T$ is the temperature of the system, $F$ is the Faraday constant and $a_{\mathrm{PbSO}_{4}}, a_{\mathrm{Pb}}, a_{\mathrm{H}^{+}}, a_{\mathrm{HSO}_{4}-}$ are the activities of the given species.

Based on Equation 1, if the lead ion or the sulfate ion activity changes on the electrochemically active surface of the electrode, the potential of the negative electrode will change too. The concentration (also the activity) of the sulfuric acid decreases continuously during discharge, due to this, the potential also gradually increases. The reason of the high change at the end of discharge is the decrease of both species' activity.

At more positive potential, other reactions can take place. The most significant reactions are the following:

$$
\begin{aligned}
& \mathrm{PbSO}_{4}+2 \mathrm{H}_{2} \mathrm{O} \rightarrow \mathrm{PbO}_{2}+\mathrm{HSO}_{4}{ }^{-}+3 \mathrm{H}^{+}+2 \mathrm{e}^{-} \\
& 2 \mathrm{H}_{2} \mathrm{O} \rightarrow 4 \mathrm{H}^{+}+\mathrm{O}_{2}+4 \mathrm{e}^{-}
\end{aligned}
$$

In Reaction 2 lead sulfate with high resistance and specific volume is converted to lead dioxide. Due to this reaction, the electrode's internal resistance is decreased and the average size of the pores is increased. In Reaction 3 (which is significant when the polarity reversal of the negative electrode takes place), oxygen gas evolves, which phenomena was observed by Garche et al. [5]. On the one hand, these gas bubbles mix the electrolyte, so the inhomogeneities can be eliminated. On the other hand, a non-conductive layer of gas is formed on the active surface resulting in increased internal resistance. If all electrochemically active lead reacted due to the Reaction 1, the potential changes (even the potential of the positive electrode can be reached) and the Reactions 2 and 3 take place. Based on this, the over-discharge of the negative electrode is very similar to the charge/over-charge of the positive electrode. During this process, the internal resistance of the electrode doesn't change significantly until the end of over-discharge.

After over-discharge, the system is left alone for 2 hours and synproportionation can occur (Reaction 4), in which the remaining lead content of the active mass reacts with lead-dioxide generated during over-discharge (Reaction 2).

$$
\mathrm{Pb}+\mathrm{PbO}_{2}+2 \mathrm{HSO}_{4}^{-}+2 \mathrm{H}^{+} \rightarrow 2 \mathrm{PbSO}_{4}+2 \mathrm{H}_{2} \mathrm{O}
$$

In this case, the concentration of sulfuric acid decreases, lead and lead dioxide with lower resistance and specific volume converted to lead sulfate with high resistance and specific volume. Based on these phenomena, pores can become clogged and the internal resistance can significantly increase.

During the recharge, both lead sulfate and lead dioxide can be converted into lead with better conductivity and lower specific volume. Although the transformation of the whole amount of lead sulfate requires a long time, the internal resistance significantly decreases during ca. 10 minutes. This phenomenon can be explained with the opening of pores and higher sulfuric acid concentration inside them which resulted in low resistivity connectors to the grid. Several hours later, the internal resistance reaches to its initial value. 


\section{Positive electrode}

The observed phenomena during discharge of the positive electrode (Figure 5) were similar to the previously mentioned ones. In Figure 5, the end of step 11, step 12 and 13 and the beginning of step 14 of Table 1 are shown. The internal resistance increased continuously as the cell lost its capacity ("normal" discharge between ca. 0-3 h) and when high decrease of the potential occurred, it increased by approximately two orders of magnitude compared to the initial value. During over-discharge (between ca. 3-8 h), it approached its initial value, and after that, when discharge was over (between ca. 8-9 h), we experienced some increase again. After starting the recharge (between ca. 9-16 h), it reached its initial value in about half an hour.

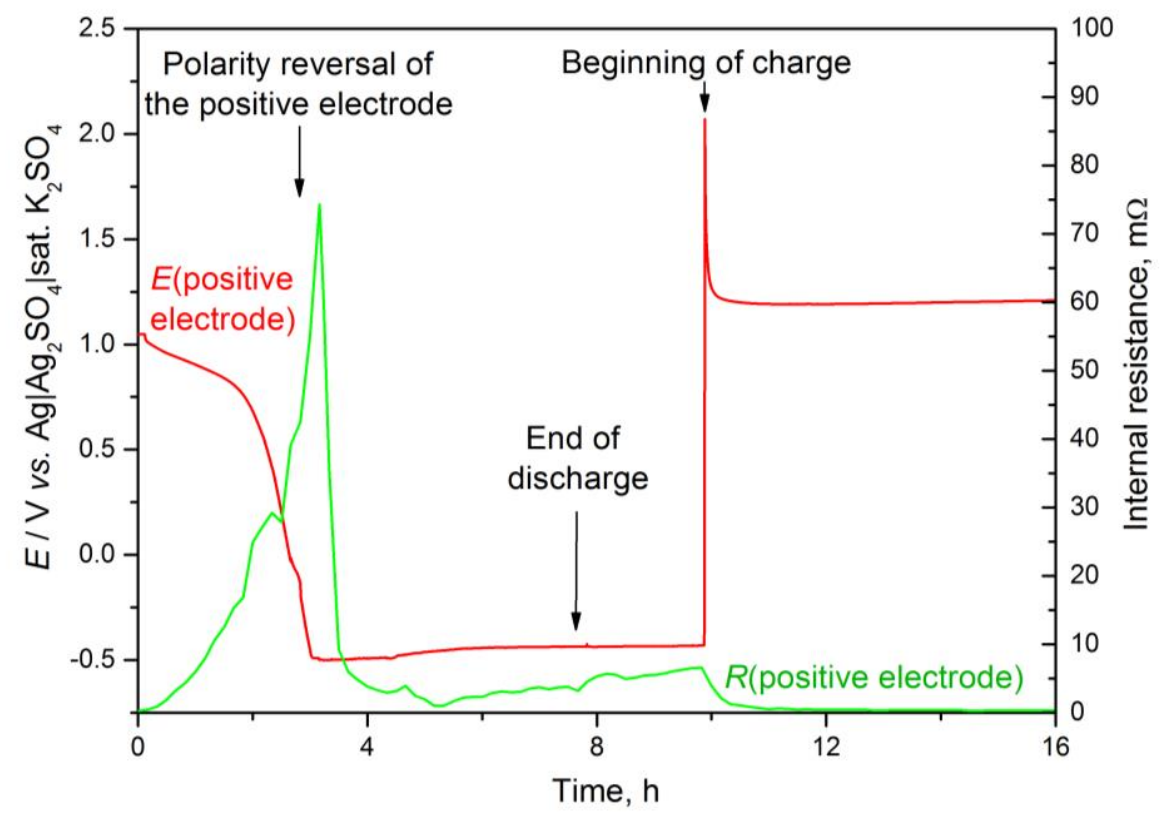

Figure 5. Change of positive electrode's potential and internal resistance during a dischargecharge cycle

In this case, the potential of the positive electrode can also be estimated from the Nernst equation.

$$
E_{\mathrm{PbO}_{2} / \mathrm{PbSO}_{4}}=E_{\mathrm{PbO}_{2} / \mathrm{PbSO}_{4}}^{o}+\frac{R T}{2 F} \ln \frac{a_{\mathrm{PbO}_{2}} a_{\mathrm{H}^{+}}^{3} a_{\mathrm{HSO}_{4}^{-}}}{a_{\mathrm{PbSO}_{4}} a_{\mathrm{H}_{2} \mathrm{O}}^{2}}
$$

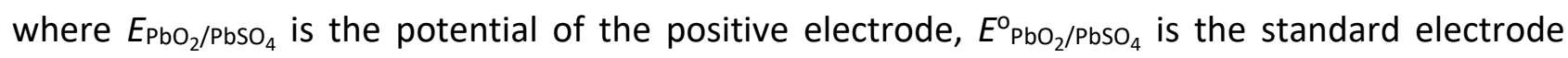
potential of the $\mathrm{PbO}_{2} / \mathrm{PbSO}_{4}$ system ( $+1.685 \mathrm{~V}$ vs. SHE), $R$ is the gas constant, $T$ is the temperature of the system, $F$ is the Faraday constant and $a_{\mathrm{PbO}_{2}}, a_{\mathrm{PbSO}_{4}}, a_{\mathrm{H}_{2} \mathrm{O}}, a_{\mathrm{H}^{+}}, a_{\mathrm{HSO}_{4}}$ - are the activities of the given species.

This case is a little bit more complex than the case of negative electrode. Although, the reason of the potential's monotone decrease is the sulfuric acid consumption, but the fall of potential can be caused by several processes: the decrease of activity of lead-dioxide (in extreme case when the battery is "fully" discharged, almost the whole surface of the active material is covered by leadsulfate, so the activity of the lead-dioxide must be less than one) or sulfuric acid or the increase of activity of water next to the electrochemically active surface (the activity of the water in such a concentrated electrolyte is less than one [10]). It can be stated that the potential doesn't change dramatically when the over-discharge of the positive electrode completed. There may be two 
different explanations: Reaction 4 isn't significant during over-discharge at all or it becomes significantly important before the process is over. It can be distinguished betweem the two possibilities by analyzing the results of the resistance measurement.

Looking at the change in internal resistance of the positive electrode, the phenomenon is similar to the case of the negative electrode. The initial increase is caused by clogged pores and high resistivity lead sulfate. The interpretation of sudden decrease in the potential is practically the same as mentioned before, but there is an important difference in the further part of overdischarge, the internal resistance begins to increase before the process is over. Based on this, it is concluded that the Reaction 4 becomes significant before over-discharge is over.

\section{Cell}

In Figure 6, the voltage of a whole cell is shown (regarding to the end of step 11, step 12 and 13 and the beginning of step 14 of Table 1). Besides the previously mentioned phenomena, interesting behavior could be observed after the cell reversal (between ca. 5-8 h) and after the over-discharge was finished (between ca. 8-10 h). The internal resistance of the cell didn't decrease during the over-discharge period as much as shown in the previous sections. This phenomenon can be justified by the worse structural properties of the active material. If the pores inside the electrodes and the electrochemically active surface of them are smaller, the effects of the same processes can be much larger as it can be seen until the beginning of recharge (between ca. 5-10 h). After the end of discharge, the internal resistance increased just as in the case of the negative and positive electrode, but the rate was much higher than it can be expected, which also refers to the poor structural properties of the electrode. But after this region, the resistance decreased (between ca. 8-10 h). If we consider that the impedance measurement has an impact on the system, it can be explained by the discharge current which was applied in every 10 minutes for a short time resulting in a decrease of internal resistance (the pulsating curve also suggests this phenomenon).

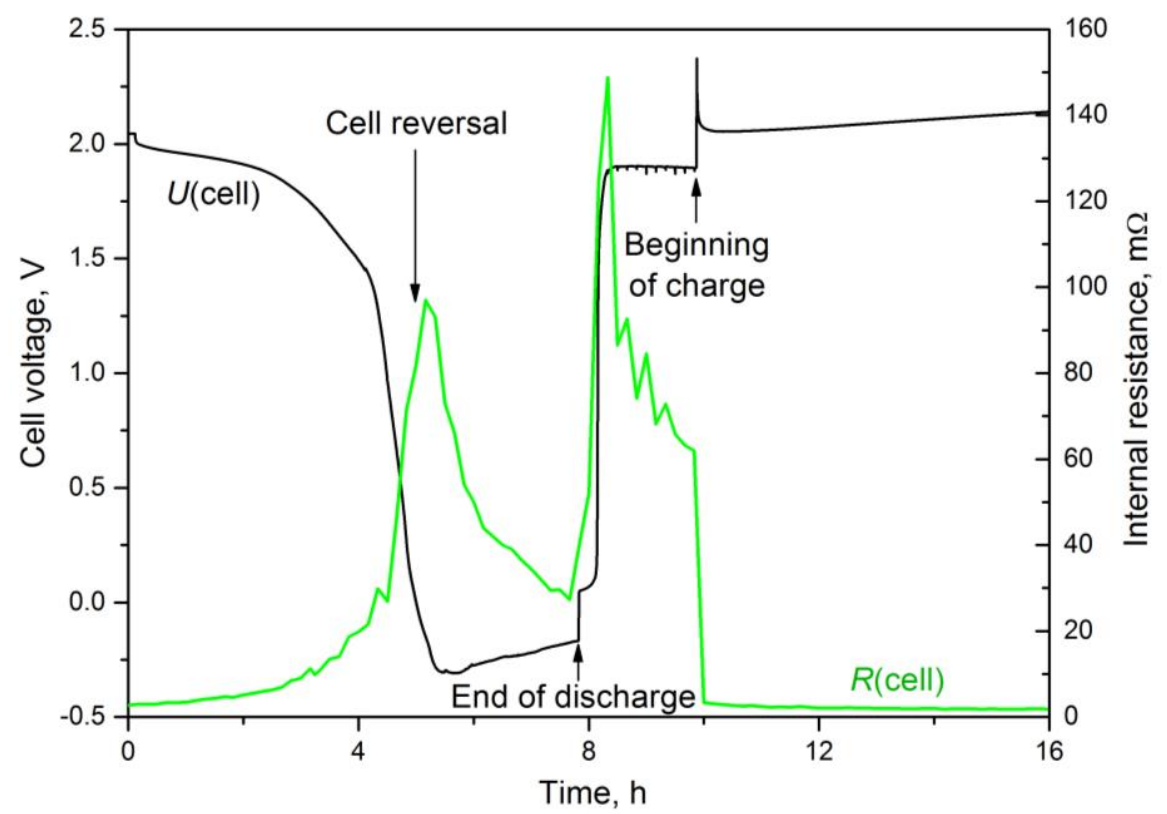

Figure 6. Change of cell's voltage and internal resistance during a discharge-charge cycle

Based on this, it can be said that during the measurements when current flowed through the system, this phenomenon hadn't caused an error, because the current was applied for a short time. It was only significant when neither discharge nor charge was executed. In the experiments 
shown in Figure 4 and Figure 5, this phenomenon was negligible because the system was not in a labile state contrast to the measurement shown in Figure 6.

\section{Temperature measurement}

\section{Over-discharge}

In Figure 7, it is shown that during the negative electrode polarity reversal, at first the value of that thermocouple changes ( $T_{\text {negative}}$ ) which is located in the direct vicinity of the negative electrode and the other ones follow later. The temperature near the positive electrode ( $T_{\text {positive }}$ )

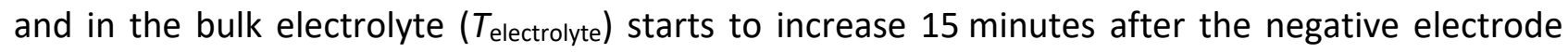
polarity reversal. According to our expectations, $T_{\text {negative }}$ changed the biggest $\left(0.4{ }^{\circ} \mathrm{C}\right), T_{\text {positive }}$ and

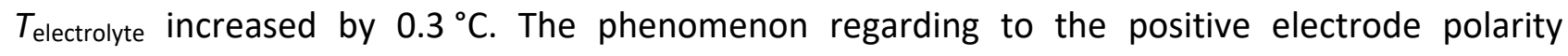
reversal was essentially the same.

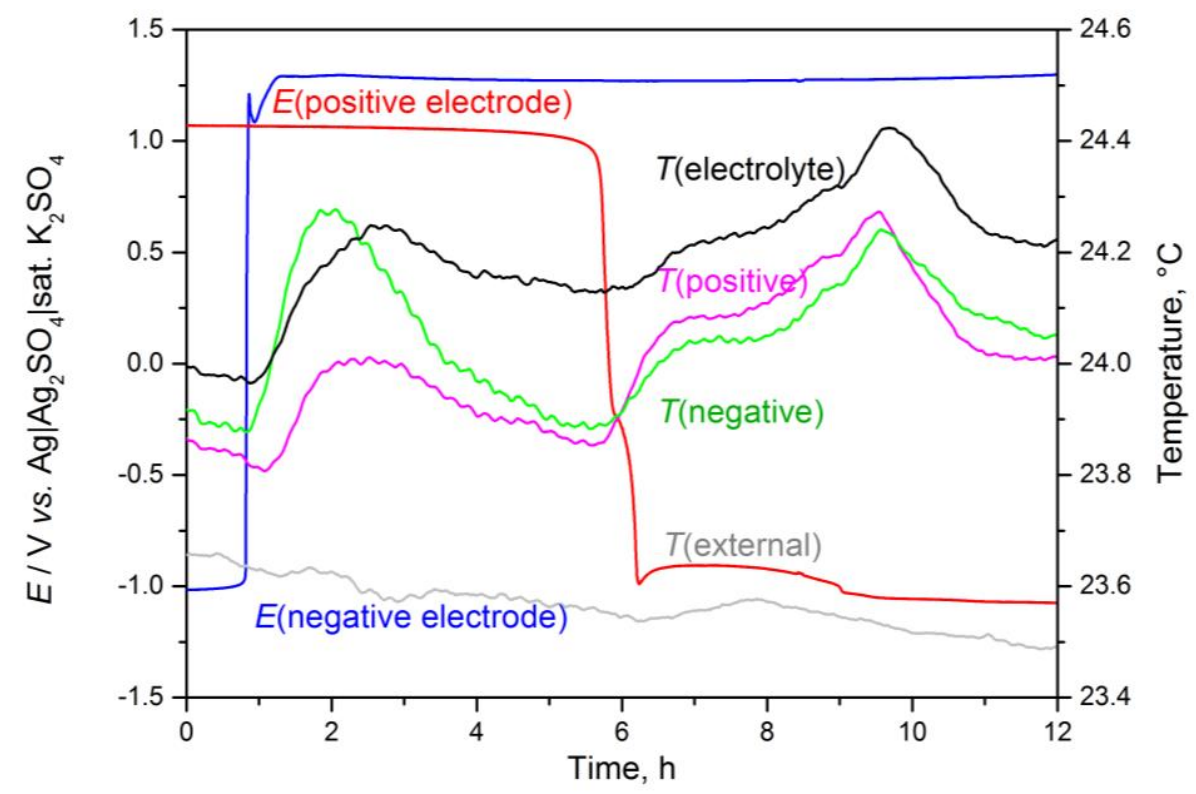

Figure 7. Temperature change due to over-discharge (potential of negative and positive electrode, temperature in the vicinity of the negative and the positive electrode, in the electrolyte and in the heat chamber)

These changes may not seem very significant at first sight, but if they are converted for the original cell, the effects are much higher. In Table 2, the most important differences between the test cell and the original cell are summarized.

Table 2. Parameters of the cells.

\begin{tabular}{ccc}
\hline & Test cell & Original cell \\
\hline Amount of electrolyte, $\mathrm{ml}$ & 650 & 75 \\
\hline Number of negative electrodes & 1 & 5 \\
\hline Number of positive electrodes & 1 & 4 \\
\hline Measured capacity, Ah & ca. 3 & ca. 8 \\
\hline
\end{tabular}

Based on the measured values by the thermocouple placed in the electrolyte, it can be assumed that the temperature of the whole cell has increased by more than $0.3^{\circ} \mathrm{C}$. During overdischarge if the same processes take place, the original cell generates about 3 times as much heat 
as the test cell based on the capacity differences. The cell voltages are practically the same in these cases, but approximately 3 times higher charge goes through the original cell than the test cell. The generated heat can be calculated as the product of voltage and charge based on Equation 5.

We need to estimate the heat capacity of the electrodes. For this calculation, we used the following molar heat capacity values: $2 \mathrm{~J} /\left(\mathrm{mol} \cdot{ }^{\circ} \mathrm{C}\right)$ for lead, $103 \mathrm{~J} /\left(\mathrm{mol} \cdot{ }^{\circ} \mathrm{C}\right)$ for lead sulfate and $61 \mathrm{~J} /\left(\mathrm{mol} \cdot{ }^{\circ} \mathrm{C}\right)$ for lead dioxide. The weight of the negative electrode is approximately $40 \mathrm{~g}$ of which the lead grid is $12 \mathrm{~g}$ and the active mass is the remaining $30 \mathrm{~g}$ (we suppose that it contains mostly lead at the beginning of the measurement). The positive electrode's weight is approximately $50 \mathrm{~g}$, of which the lead grid is $12 \mathrm{~g}$ and the active mass is $38 \mathrm{~g}$ (we suppose that it is mostly lead dioxide at the beginning). By the time the cell was discharged, approximately 3 Ah of charge was passed through it. According to the Faraday law, it is possible to calculate how much active mass was converted during discharge procedure (Table 3, Table 4).

Table 3. Transformation of active material and sulfuric acid in the test cell during discharge

\begin{tabular}{ccccccc}
\hline & Negative electrode & \multicolumn{2}{c}{ Positive electrode } & \multicolumn{2}{c}{ Electrolyte } \\
\hline Compound & Lead & $\begin{array}{c}\text { Lead } \\
\text { sulfate }\end{array}$ & $\begin{array}{c}\text { Lead } \\
\text { dioxide }\end{array}$ & $\begin{array}{c}\text { Lead } \\
\text { sulfate }\end{array}$ & Sulfuric acid & Water \\
\hline$m_{\text {beg }} / \mathrm{g}$ & 28 & 0 & 38 & 0 & 308 & 524 \\
\hline$m_{\text {trans }} / \mathrm{g}$ & -12 & +17 & -13 & +17 & -11 & +2 \\
\hline$m_{\text {end }} / \mathrm{g}$ & 16 & 17 & 25 & 17 & 297 & 526 \\
\hline
\end{tabular}

We used the following data for the calculation: $\rho(37 \mathrm{~m} / \mathrm{m} \%$ sulfuric acid $)=1.28 \mathrm{~g} / \mathrm{cm}^{3}$; $M(\mathrm{~Pb})=207.2 \mathrm{~g} / \mathrm{mol} ; \quad M\left(\mathrm{PbSO}_{4}\right)=303.3 \mathrm{~g} / \mathrm{mol} ; \quad M\left(\mathrm{PbO}_{2}\right)=239.2 \mathrm{~g} / \mathrm{mol} ; \quad M\left(\mathrm{H}_{2} \mathrm{SO}_{4}\right)=98.1 \mathrm{~g} / \mathrm{mol} ;$ $M\left(\mathrm{H}_{2} \mathrm{O}\right)=18.0 \mathrm{~g} / \mathrm{mol} ; \mathrm{F}=96500 \mathrm{C} / \mathrm{mol}$.

Table 4. Transformation of active material and sulfuric acid in the original cell during discharge.

\begin{tabular}{ccccccc}
\hline & Negative electrode & \multicolumn{2}{c}{ Positive electrode } & \multicolumn{2}{c}{ Electrolyte } \\
\hline Compound & Lead & $\begin{array}{c}\text { Lead } \\
\text { sulfate }\end{array}$ & $\begin{array}{c}\text { Lead } \\
\text { dioxide }\end{array}$ & Compound & Lead & $\begin{array}{c}\text { Lead } \\
\text { sulfate }\end{array}$ \\
\hline$m_{\text {beg }} / \mathrm{g}$ & 140 & 0 & 152 & 0 & 36 & 61 \\
\hline$m_{\text {trans }} / \mathrm{g}$ & -31 & +45 & -36 & +45 & -29 & +5 \\
\hline$m_{\text {end }} / \mathrm{g}$ & 109 & 45 & 116 & 45 & 6 & 66 \\
\hline
\end{tabular}

Based on the measured capacity of the original cell, it is stated that approximately 8 Ah charges could pass through the cell until reaching the fully discharged state. At that time, the mass fraction of the sulfuric acid in the test cell was $36 \mathrm{~m} / \mathrm{m} \%$ [heat capacity $=2.9 \mathrm{~J} /\left(\mathrm{g} \cdot{ }^{\circ} \mathrm{C}\right)$ ] and it was $9 \mathrm{~m} / \mathrm{m} \%$ in the original cell [heat capacity $=3.9 \mathrm{~J} / \mathrm{g} \cdot{ }^{\circ} \mathrm{C}$ ). [11]

Based on Table 3, Table 4 and the above-mentioned data, the heat capacity of the cells can be calculated (active mass+grid+electrolyte): $C_{\text {test cell }}=2410 \mathrm{~J} /{ }^{\circ} \mathrm{C}, C_{\text {original cell }}=374 \mathrm{~J} /{ }^{\circ} \mathrm{C}$.

We can make a calculation to estimate the generated heat $\left(Q_{\text {test cell }}\right)$ in the test cell:

$Q_{\text {test cell }}=C_{\text {test cell }} \Delta T_{\text {test cell }}=2410 \mathrm{~J} /{ }^{\circ} \mathrm{C} \times 0.3^{\circ} \mathrm{C}=723 \mathrm{~J} \approx Q_{\text {original cell }} / 3$

where $\Delta T_{\text {test cell }}$ is the temperature change during the negative electrode polarity reversal, $Q_{\text {orginal cell }}$ is the generated heat in the original cell due to the previously mentioned effect. 
Based on this, we can roughly calculate how many degrees of Celsius the original cell will warm with the same current density and process:

$$
\Delta T_{\text {original cell }}=Q_{\text {original cell }} \approx \frac{732 \mathrm{~J} \times 3}{364 \frac{\mathrm{J}}{{ }^{\circ} \mathrm{C}}}=5.8{ }^{\circ} \mathrm{C}
$$

The temperature in the original cell would increase by about $6{ }^{\circ} \mathrm{C}$ due to the electrode polarity reversal. However, it is important to note that this will be the average value in the whole cell, so inside the electrode, the temperature can rise significantly higher which has a very significant role in aging processes. [12]

It can be assumed that not the different reactions cause the temperature rise, because the system cools down later and it approaches its initial state in the vicinity of the electrodes' surface, although the reactions don't change significantly at that time. However, the high resistance increase can cause this phenomenon.

The initial resistance of the cell was $0.02 \Omega$, the current (I) during the whole procedure was $0.16 \mathrm{~A}$, the duration $(t)$ of the temperature rise (also the duration of the high resistance increasing) was approximately 1 hour. The generated heat $(Q)$ can be estimated from Equation 5.

$$
Q=P t=U_{\text {cell }} I t=R I^{2} t
$$

where $P$ is the electrical power, $U_{\text {cell }}$ is the cell voltage and $R$ is the resultant resistance.

We can calculate the resultant resistance from Equation 6.

$$
R=\frac{Q}{l^{2} t}=\frac{723 \mathrm{~J}}{(0.16 \mathrm{~A})^{2} \times 3600 \mathrm{~s}} \approx 8 \Omega
$$

Although the calculation contains many approximations and estimates, it shows that the resultant resistance, as in the previous section, increased by more than two orders of magnitude during over-discharge process (when the potential of the electrode and the temperature greatly changed at the same time).

"Recharge"

The recharging of an over-discharged cell is shown in Figure 8.

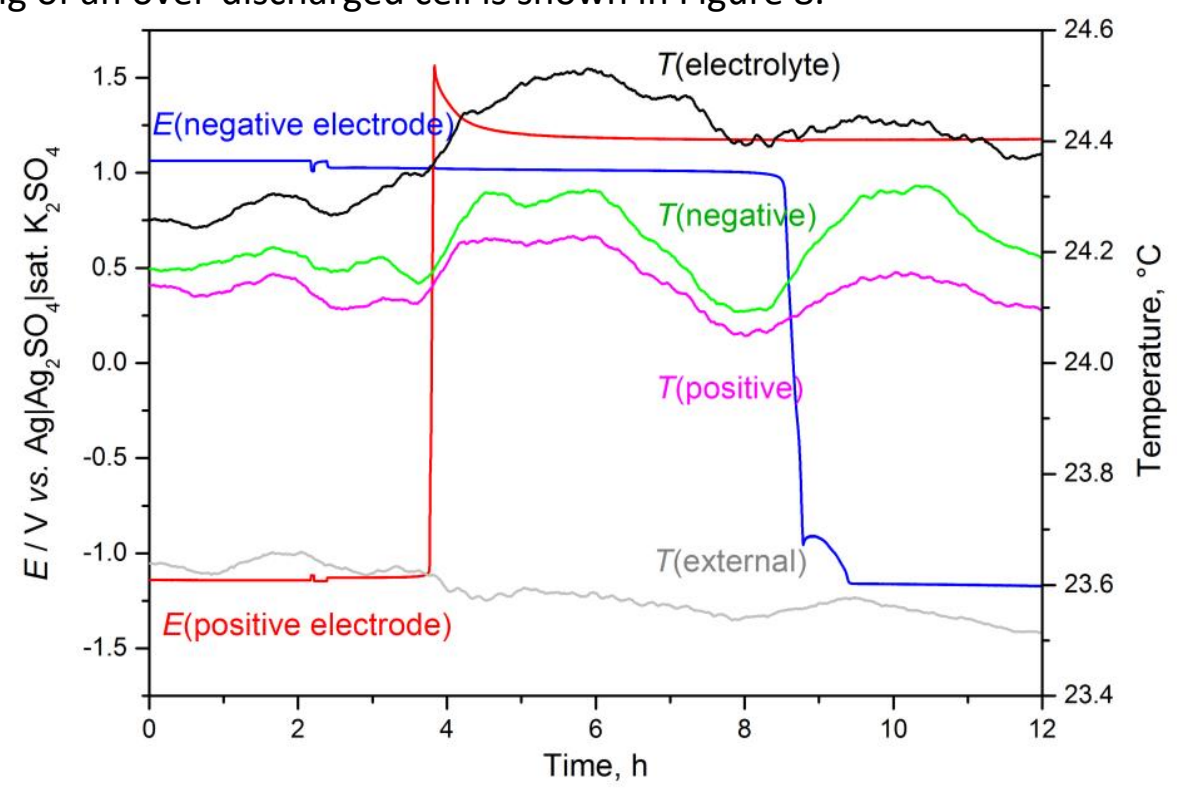

Figure 8. Temperature change due to "recharge" (potential of negative and positive electrode, temperature in the vicinity of the negative and the positive electrode, in the electrolyte and in the heat chamber) 
During the recharging, temperature rise was also experienced which was similar to the previously described one (during over-discharge) and the heat capacity of the cell was practically the same. Based on these results, we can state that the internal resistance of the examined cell increased by several orders of magnitude compared to its initial value during the recharging.

\section{Conclusions}

By investigating a lead-acid test cell, it was proved that the internal resistance highly increased during the cell reversal. This process and the increasing gas evolution caused significant temperature to rise inside the electrode undergoing the reversal and consequently in the whole cell. This is a very reproducible phenomenon which has a serious influence on aging specifically on the loss of capacity because there is high temperature increase and gas flow at the same time.

Acknowledgements: Financial and spiritual support from the Bolyai Collage is gratefully acknowledged.

\section{References}

[1] P. Ruetschi, Journal of Power Sources 127 (2004) 33-44.

[2] T. B. Reddy, Linden's Handbook of Batteries, Elsevir, New York, USA, 2002

[3] J. Garche, E. Karden, P. T. Moseley, D. A. J. Rand, Lead-Acid Batteries for Future Automobiles, Elsevir, Amsterdam, Netherland, 2017

[4] L. G. Mallison, Ageing Studies and Lifetime Extension of Materials, Springer, Oxford, United Kingdom, 2001

[5] J. Garche, A. Jossen, H. Doring, Journal of Power Sources 67 (1997) 201-212.

[6] T. Blank, J. Badeda, J. Kowal, D. U. Sauer, IEEE Conference, Deep discharge behavior of lead-acid batteries and modeling of stationary battery energy storage systems, Scottsdale, USA, 2012, p. 1-4.

[7] D. Pavlov, Lead-Acid Batteries: Science and Technology, Elsevier, Oxford, United Kingdom, 2011, p. 178.

[8] G. Bárány, Lead-acid battery state detection for automotive electrical energy management, PhD dissertation, Budapest University of Technology and Economics, 2015, p. 70-81.

[9] H. Bode, Lead-Acid-Batteries, John Wiley \& Sons, New York, United States, 1977

[10] K. R. Bullock, Journal of Power Sources 35 (1991) 197-223.

[11] J. E. Kunzler, W. F. Giauque, Journal of the American Chemical Society 74 (1952) 3472-3476.

[12] A. Jossen, H. Karl, G. Lehner, F. Hummel, 9. Symposium Photovoltaische Solarenergie, Betriebserfahrungen mit unterschiedliechen Bleibatterien, Bad Staffelstein, Germany, 1994, p. 271.

(C)2018 by the authors; licensee IAPC, Zagreb, Croatia. This article is an open-access article distributed under the terms and conditions of the Creative Commons Attribution license

(http://creativecommons.org/licenses/by/4.0/) 